\title{
Indicators of the Condition of Newborn Calves after Difficult Labor Syndrome
}

\author{
Sergey Loshchinin, Vladimir Avdeenko*, and Alena Filatova \\ Federal State Budgetary Educational Institution of Higher Education Saratov State Agrarian \\ University named after N.I. Vavilov, Russia, 410012, Saratov, 1 Teatralnaya Ploshchad
}

\begin{abstract}
Difficult Labor Syndrome is recorded in $37.9 \%$ of newborn calves. Newborn calves assessed on the Apgar scale of 2 points, are assigned to the cluster class born after easy labor, 1 point - after moderate labor and 0 points for difficult labor. The characteristic features of newborn calves after light birth are the manifestation of statistical functions and free movement. In newborn calves born with moderate and severe labor severity, weakly expressed motor-food reflexes are manifested. Visible mucous membranes are pale in color. Breathing is slow and shallow. Heart sounds are weak, the pulse is arrhythmic, slowed down with a decrease in the pulse wave. Decrease in glucose concentration, increase in total bilirubin level by 1.9 times with moderate severity of labor and 2.5 times with severe course of labor. An excess of creatinine contributes to the liborilization of the function of eosinophils, as a result, a symptom develops due to sensitization of the body. The activity of gammalutamyl transpeptidase in newborn calves after the Difficult Labor Syndrome in one hour increases 18.6 times, the activity of alkaline phosphatase during this period increases 1.5 times, aspartate aminotransferase and alanine aminotransferase - 1.6 times, lactate dehydrotransferase - 1.3 times. The most significant increase in the first 24 hours is the activity of $\gamma$-glutamyl transferase. At the age of one day, it exceeds the initial one by 95.6 times. The studies carried out indicate that the concentration of double bonds in the blood of newborn calves after the Difficult Labor Syndrome is marked by an increase of $20.46 \%$ with an average severity of labor and $34.13 \%$ with a severe course of labor when compared with a mild severity of labor. The level of diene conjugates in the blood of newborn calves with mild labor severity in comparison with moderate labor severity was statistically significantly increased $(\mathrm{p}<0.05)$, and 1.87 times with severe labor $(\mathrm{p}<0.01)$. The concentration of intermediate products of ketodienes and conjugated trienes in the blood of newborn calves with mild labor severity was statistically significantly increased by 1.75 times compared with moderate labor severity and 3.54 times with severe labor $(p<0.01)$. Reduced glutathione is among the considered indicators of the least sensitivity $(26.0 \%)$ and specificity $(43.0 \%)$ in newborn calves after the Difficult Labor Syndrome.
\end{abstract}

*Corresponding author: avdeenko8686@mail.ru 


\section{Introduction}

According to veterinary statistics, diseases of newborn calves occupy one of the leading places in the structure of morbidity in dairy cattle. According to studies carried out by S.O. Loshchinin et al. [1], the mechanism of development of neonatal pathology is quite complex and has a multifactorial nature. Research by $\mathrm{Yu}$. N. Alekhin [3] showed that the factors predisposing for most forms of antenatal, intranatal and neonatal pathology are violations of the technology of full and balanced feeding, keeping, and exploitation of the broodstock, the principles of obstetric care and the sanitary and hygienic regime of keeping newborns.

The consequences of re-illing animals in the neonatal period are observed throughout life. Wherein, the exterior deteriorates, resistance, productivity and fertility and further reproductive ability of such animals decrease. In modern economic conditions, the owners of productive animals have a widespread misunderstanding and unwillingness to reckon with the requirements of life support for highly productive animals in farms of various organizational and legal forms of ownership.

Observations of S.O. Loshchinina et al., [2] show unequal viability of newborn calves obtained from women in labor with normal and prolonged calving, while the number of difficult births in dairy cattle ranges from 13.0 to $20.0 \%$ of the total number of births.

According to data published by A. A. Kataranov [4] and A. S. B. Berge, T. E. Besser, D. A. Moore, W. M. Sischo [5], shortly after birth, newborn calves undergo physiological and biochemical changes associated with formation of a new metabolic status and high energy requirements.

However, according to the results of M. Epiney, F. Boehlen, M. Boulvain et. al., [6], it can be concluded that without studying the metabolic status and antioxidant system of protecting the health of newborn calves, it is impossible to develop effective methods for relieving the Difficult Labor Syndrome, as well as to carry out resuscitation measures and, subsequently, rehabilitation methods for the prevention of neonatal pathology. The need for an integrated approach to formation of a methodology for prevention of pathological childbirth in mothers - parturient women and the Difficult Labor Syndrome in newborn calves is evidenced by the published paper of M. R. Syme, J. W. Paxton, J. A. Keelan [6].

Goal and tasks. Establishment of indicators of the state of newborn calves after the Difficult Labor Syndrome.

\section{Methods}

Clinical studies, as well as analysis of field material were carried out on 1095 pregnant cows and 300 newborn calves with Difficult Labor Syndrome after obstetrics for dystocia, uterine inversion, cesarean section and retention of the placenta using classical, generally accepted methods in veterinary medicine. For hematological studies, we used a veterinary automatic hematological blood analyzer Abacus Junior Pse 90 Vet (Automatic Veterinary manufactured in Germany) and a biochemical blood analyzer Chem Well combi Models 2902 and 2910 (manufactured in the USA, Florida). With the total number of animals, the degree of spread of neonatal pathology in calves was determined according to certain clinical symptoms that characterize the manifestation of the pathological process. Through clinical observations and timing, the syndromatics and duration of diseases in newborn calves were studied. Clinical examination of animals was carried out using conventional methods: organized collection of anamnesis, analysis of clinical examination of newborn calves. Short-term recording of the heart rate was carried out in the morning at a temperature of $20-22{ }^{\circ} \mathrm{C}$. In the paper, the investigated values were presented in the form of a sample mean and standard error of the mean. The significance of differences in the mean 
values of independent samples was assessed using the parametric Student's test and nonparametric Mann-Whitney tests, depending on the type of distribution of indicators. Statistical comparison of the proportions with the assessment of the significance of differences was performed considering the Yates' correction for continuity. All statistical procedures were performed using the Statistica 6.0 software package.

\section{Results}

Clinical assessment of the state of newborn calves after the Difficult Labor Syndrome served as indicators of the Apgar scale used by us. Using these changes in clinical parameters, a differential table was developed for assessing the severity of viability in newborn calves during the first hours after birth (Table 1).

Table 1. Clinical assessment of newborn calves after the Difficult Labor Syndrome.

\begin{tabular}{|l|l|l|l|}
\hline \multirow{2}{*}{ Signs } & \multicolumn{1}{|c|}{ Score in points } \\
\cline { 2 - 4 } Palpitations & $100-140 \mathrm{bpm}$ & $\begin{array}{l}\text { 50-100 } \\
\text { bpm }\end{array}$ & $\begin{array}{l}\text { Less than 50 } \\
\text { bpm. }\end{array}$ \\
\hline Breath & $40-60 \mathrm{bpm}$ & $\begin{array}{l}\text { Slow breathing, } \\
\text { shallow }\end{array}$ & $\begin{array}{l}\text { Rare single } \\
\text { respiratory } \\
\text { movements }\end{array}$ \\
\hline $\begin{array}{l}\text { Color of visible mucous } \\
\text { membranes }\end{array}$ & Pink & $\begin{array}{l}\text { Weak pink } \\
\text { with a bluish } \\
\text { tinge }\end{array}$ & $\begin{array}{l}\text { White or } \\
\text { strongly } \\
\text { cyanotic }\end{array}$ \\
\hline Muscle tone & $\begin{array}{l}\text { Active } \\
\text { movements }\end{array}$ & Reduced & Missing \\
\hline Reflex excitability & $\begin{array}{l}\text { Head } \\
\text { movement } \\
\text { with a well- } \\
\text { pronounced } \\
\text { corneal reflex }\end{array}$ & Good & Missing \\
\hline $\begin{array}{l}\text { Manifestation of the } \\
\text { corneal reflex }\end{array}$ & $\begin{array}{l}\text { The corneal } \\
\text { reflex } \\
\text { appears }\end{array}$ & $\begin{array}{l}\text { The corneal } \\
\text { reflex appears }\end{array}$ & $\begin{array}{l}\text { No corneal } \\
\text { reflex }\end{array}$ \\
\hline
\end{tabular}

The data presented in Table 1 indicate the viability of newborn calves after birth with the Difficult Labor Syndrome and their ability to adapt to environmental conditions. Newborn calves assessed by clinical status at 2 points, were attributed by us to the cluster class born after easy labor, and 1 point - after moderate labor and 0 points for difficult labor.

Statistical analysis of our data showed that the characteristic features of newborn calves after easy birth are moderate manifestation of motor-food reflexes, good appetite, normal frequency of bowel movements and urination. Timely display of statistical functions and free movement. Gently velvety skin with well-developed subcutaneous fat layer and smooth, shiny hair. Developed skeleton without rickety abnormalities.

Wherein, newborn calves born with moderate and severe labor are characterized by poorly expressed motor and food reflexes. Visible mucous membranes are pale in color. The skin in the neck and tail folds has pronounced folds. Sunken eyes. Breathing is slow and shallow. Heart sounds are weak, the pulse is arrhythmic, slowed down with a decrease in the pulse wave. A heart beat is felt on both sides of the chest.

Central venous pressure in newborn calves was determined by a direct method by catheterization of the jugular vein, and the urinary flow rate was also measured. Every 
thirty minutes, then one hour, three hours, twelve hours, three days, the urine excreted by the calves was collected in a graduated dish and its volume was measured. The materials obtained are provided in Figures 1, 2.

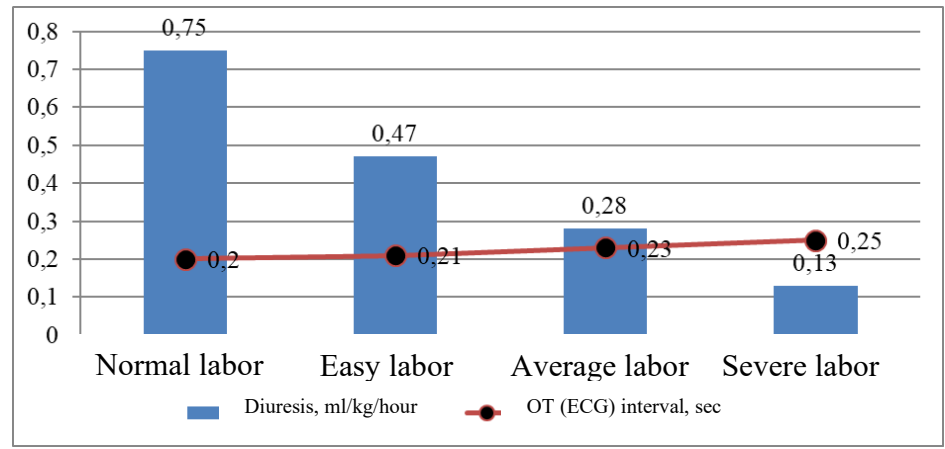

Fig. 1. Indices of urine output and OT interval in newborn calves after the Difficult Labor Syndrome.

Diuresis in newborn calves after normal delivery is $0.75 \pm 0.02 \mathrm{ml} / \mathrm{kg} / \mathrm{h}$. Whereas, in newborn calves after a mild severity of labor, the urinary flow rate is $0.47 \pm 0.05 \mathrm{ml} / \mathrm{kg} / \mathrm{h}$. With an average severity of labor $-0.28 \pm 0.03 \mathrm{ml} / \mathrm{kg} / \mathrm{h}$, while in severe labor, the rate of diuresis does not exceed $0.13 \pm 0.02 \mathrm{ml} / \mathrm{kg} / \mathrm{h}$.

In newborn calves after a mild severity of labor, the central venous pressure practically did not differ from the indices of newborn calves after normal birth and is $7.5 \pm 0.1 \mathrm{~cm}$ water column, while with an average severity of childbirth, it decreases to $6.3 \pm 0.4 \mathrm{~cm}$ water column $(\mathrm{p}<0.05)$, and in severe childbirth reaches $2.2 \pm 0.1$ water column $(\mathrm{p}<0.01)$.

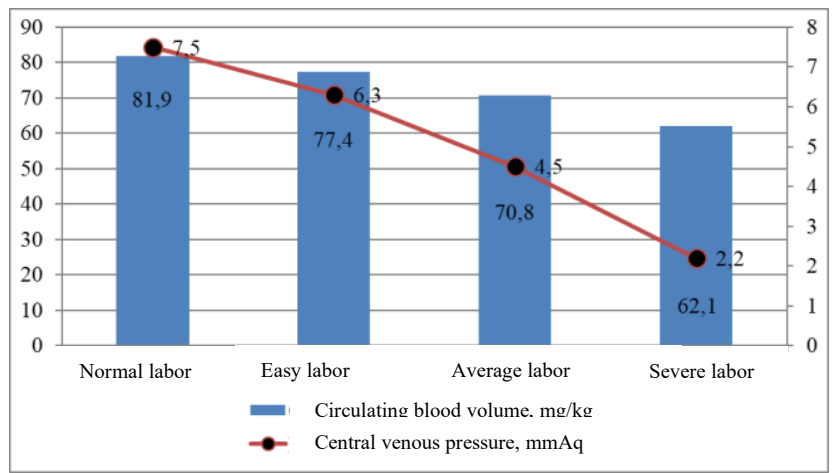

Fig. 2. Indicators of systemic hemodynamics in newborn calves after the Difficult Labor Syndrome.

Therefore, we noted a tendency for an increase in blood pressure in newborn calves after a mild severity of labor by $13.4 \%$, with an average severity of $27.8 \%$, and in severe labor by $38.8 \%$, of the indicators of newborn births after normal childbirth.

Experimental studies indicate that certain biochemical changes occur in the body of newborn calves during the neonatal period. Therefore, there is a significant decrease in the synthesis of the albumin fraction, the so-called storage proteins in the blood of newborn calves - an unfavorable sign that indicates a decrease in the protective compensatory mechanisms of the newborn organism. 
Table 2. Biochemical parameters of blood in newborn calves after Difficult Labor Syndrome.

\begin{tabular}{|l|c|c|c|}
\hline \multicolumn{1}{|c|}{ Indicators } & \multicolumn{3}{c|}{ Labor } \\
\hline & Lungs $(\mathbf{n}=\mathbf{1 5})$ & Medium $(\mathbf{n}=\mathbf{1 5})$ & Severe $(\mathbf{n}=\mathbf{1 5})$ \\
\hline Albumin, $\mathrm{g} / \mathrm{l}$ & $31.2 \pm 1.9$ & $25.3 \pm 3.20^{*}$ & $15.4 \pm 2.22^{* *}$ \\
\hline Glucose, $\mathrm{mmol} / \mathrm{l}$ & $5.1 \pm 0.03$ & $4.0 \pm 0.03^{*}$ & $2.6 \pm 0.09^{* *}$ \\
\hline Cholesterol, $\mathrm{mmol} / 1$ & $3.10 \pm 0.21$ & $4.71 \pm 0.24^{*}$ & $5.61 \pm 0.18^{*}$ \\
\hline Urea, $\mathrm{mmol} / \mathrm{l}$ & $2.5 \pm 0.02$ & $3.8 \pm 0.02^{*}$ & $4.3 \pm 0.04^{* *}$ \\
\hline Creatinine, $\mu \mathrm{mol} / 1$ & $87.1 \pm 1.34$ & $110.1 \pm 2.15^{* *}$ & $129.1 \pm 2.06^{* *}$ \\
\hline Direct bilirubin, $\mu \mathrm{mol} / 1$ & $2.26 \pm 0.03$ & $2.39 \pm 0.04$ & $2.52 \pm 0.04^{*}$ \\
\hline Total bilirubin, $\mu \mathrm{mol} / 1$ & $5.33 \pm 1.15$ & $6.26 \pm 1.17$ & $10.1 \pm 1.11^{*}$ \\
\hline
\end{tabular}

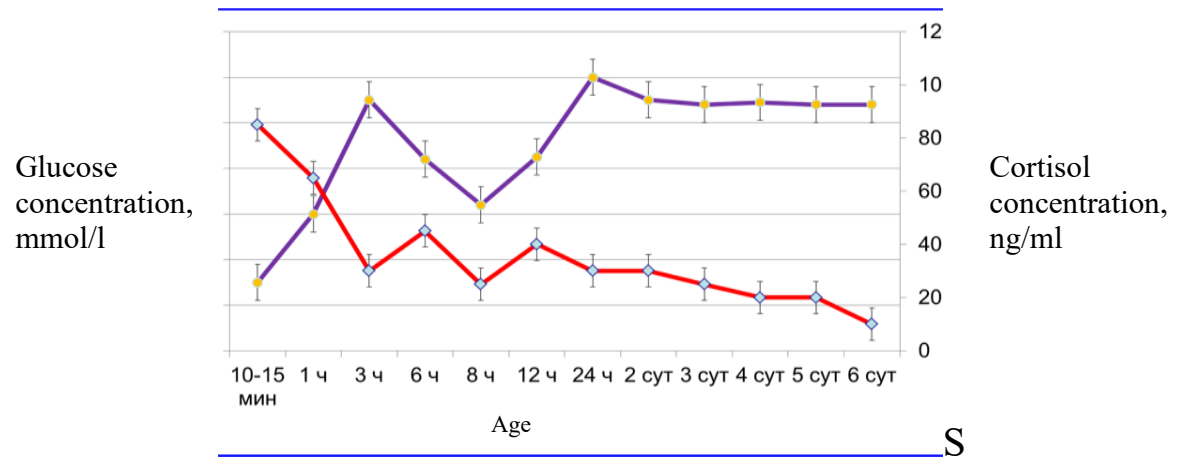

Fig. 3. The average value of the concentration of glucose and cortisol in the blood serum of newborn calves after the Difficult Labor Syndrome.

As follows from the data obtained, the cholesterol level in all newborn calves without exception after the Difficult Labor Syndrome was higher than with an average (4.71 \pm 0.24$)$ and severe severity of labor $(5.61 \pm 0.18)$, compared with newborn calves $(3.10 \pm 0.21)$ after normal delivery $(p<0.05)$. Moreover, the concentration of cholesterol in newborn calves with severe labor is significantly higher than in newborn calves with moderate labor, at $p<0.05$.

The content of creatinine in the blood serum of newborn calves after spontaneous delivery averages $87.1 \pm 1.34 \mu \mathrm{mol} / \mathrm{l}$. Wherein, in newborn calves with an average severity of labor, this indicator was 1.26 times, and with a severe degree of labor -1.48 times higher $(p<0.01)$. There is an increase in total bilirubin $(p<0.05)$ in newborn calves after the Difficult Labor Syndrome with an absolute increase in direct bilirubin by 1.05 times with average severity of labor and 1.11 times with severe severity of labor $(p<0.05)$, while the ratio of total bilirubin increases by 1.17 times with an average severity of labor and 1.89 times with a severe severity of the labor process $(p<0.05)$, respectively, compared with indicators of newborn calves after normal childbirth.

A significant deviation was noted in the indicators of glycogenesis (Table 9), which is associated with the consumption of glucose, the content of which is associated with a decrease in the glucolytic function by 1.28 times with an average severity of childbirth ( $p$ $<0.05)$ and 1.96 times with a severe degree the severity of the birth process $(p<0.01)$. 
Table 3. Dynamics of some indicators of blood carbohydrate metabolism.

\begin{tabular}{|c|c|c|c|c|c|c|c|c|}
\hline \multirow{3}{*}{$\begin{array}{c}\text { Indicat } \\
\text { ors } \\
\mathrm{mg} \%, \\
\mathrm{n}=5\end{array}$} & \multicolumn{8}{|c|}{ Time of blood collection after birth (in hours) } \\
\hline & \multicolumn{2}{|c|}{1 hour } & \multicolumn{2}{|c|}{6 hours } & \multicolumn{2}{|c|}{12 hours } & \multicolumn{2}{|c|}{24 hours } \\
\hline & norm. & ind. & norm. & ind. & norm. & ind. & norm. & ind. \\
\hline $\begin{array}{l}\text { Sum of } \\
\text { sugars }\end{array}$ & $\begin{array}{c}100 \pm 3 . \\
47\end{array}$ & $\begin{array}{c}126 \pm 4 . \\
57\end{array}$ & $\begin{array}{c}104.4 \pm 3 \\
33\end{array}$ & $\begin{array}{c}102.2 \pm 3 \\
33\end{array}$ & $\begin{array}{c}122.8 \pm 3 \\
82\end{array}$ & $\begin{array}{c}125.4 \pm 3 \\
74\end{array}$ & $\begin{array}{c}138.0 \pm 3 \\
41\end{array}$ & $\begin{array}{c}144.8 \pm 3 \\
67\end{array}$ \\
\hline $\begin{array}{l}\text { Glucos } \\
\mathrm{e}\end{array}$ & $\begin{array}{c}63.2 \pm 3 . \\
42\end{array}$ & $\begin{array}{c}82.8 \pm \\
2.63\end{array}$ & $\begin{array}{c}61.0 \pm 2.9 \\
1\end{array}$ & $\begin{array}{c}60.2 \pm 2.6 \\
3\end{array}$ & $\begin{array}{c}80.0 \pm 2.9 \\
1\end{array}$ & $\begin{array}{c}82.2 \pm 2.8 \\
1\end{array}$ & $\begin{array}{c}98.0 \pm 2.5 \\
4\end{array}$ & $\begin{array}{c}100.0 \pm 2 \\
72\end{array}$ \\
\hline $\begin{array}{l}\text { Lactic } \\
\text { acid }\end{array}$ & $\begin{array}{c}23.6 \pm 2 . \\
53\end{array}$ & $\begin{array}{c}62.6 \pm 2 \\
44\end{array}$ & $\begin{array}{c}21.6 \pm 2.5 \\
3\end{array}$ & $\begin{array}{c}42.6 \pm 2.8 \\
3\end{array}$ & $\begin{array}{c}22.8 \pm 2.5 \\
9\end{array}$ & $\begin{array}{c}31.2 \pm 2.5 \\
1\end{array}$ & $\begin{array}{c}19.8 \pm 2.3 \\
1\end{array}$ & $\begin{array}{c}29.6 \pm 2.7 \\
3\end{array}$ \\
\hline
\end{tabular}

Three hours after drinking the first portion of colostrum, it increases, but by the eighth hour of life it decreased 3.33 times. The concentration of glucose in the blood by the eighteenth hour after birth significantly increased and stabilized by the first day after birth. Changes in the concentration of glucose in the blood due to glyconeogenesis serve as a physiological mechanism of adaptation in the neonatal period, when the pancreas and liver are still insufficiently functioning. The maximum value of glucose concentration in the blood of newborns was noted by us one hour after birth, which may be the result of the glyconeogenesis process associated with an increase in the activity of the sympathetic part of the central nervous system.

The studies carried out indicate that the concentration of double bonds in the blood of newborn calves after the Difficult Labor Syndrome is noted to increase by $20.46 \%$ with an average severity of labor and $34.13 \%$ with a severe course of labor when compared with a mild severity of labor (Table 4).

Table 4. Fluctuations of the primary, intermediate and end products of LPO in the blood of newborn calves after the Difficult Labor Syndrome.

\begin{tabular}{|l|c|c|c|}
\hline \multirow{2}{*}{\multicolumn{1}{|c|}{ Indicators }} & \multicolumn{3}{c|}{ Labor } \\
\cline { 2 - 4 } & $\begin{array}{c}\text { lungs } \\
(\mathrm{n}=15)\end{array}$ & $\begin{array}{c}\text { average } \\
(\mathrm{n}=15)\end{array}$ & $\begin{array}{c}\text { severe } \\
(\mathrm{n}=15)\end{array}$ \\
\hline $\begin{array}{l}\text { Isolated double bonds } \\
\text { (conventional units) }\end{array}$ & $1.386 \pm 0.4$ & $1.644 \pm 0.41^{*}$ & $1.859 \pm 0.3^{* *}$ \\
\hline Diene conjugates $(\mu \mathrm{mol} / \mathrm{L})$ & $0.372 \pm 0.07$ & $0.509 \pm 0.19^{*}$ & $0.695 \pm 0.32^{* *}$ \\
\hline $\begin{array}{l}\text { Ketodienes and conjugated trienes (conv. } \\
\text { units) }\end{array}$ & $0.106 \pm 0.07$ & $0.186 \pm 0.05^{*}$ & $0.375 \pm 0.12^{* *}$ \\
\hline Manol dialdehyde $(\mu \mathrm{mol} / \mathrm{L})$ & $1.125 \pm 0.34$ & $1.251 \pm 0.26$ & $1.519 \pm 0.54^{*}$ \\
\hline A-tocopherol $(\mu \mathrm{mol} / \mathrm{L})$ & $8.16 \pm 0.38$ & $7.57 \pm 0.41$ & $6.98 \pm 0.59$ \\
\hline Retinol $(\mu \mathrm{mol} / \mathrm{L})$ & $2.523 \pm 0.52$ & $1.785 \pm 0.39$ & $1.543 \pm 0.61$ \\
\hline Reduced glutathione $(\mu \mathrm{mol} / \mathrm{l})$ & $1.546 \pm 0.16$ & $1.756 \pm 0.34$ & $2.054 \pm 0.44$ \\
\hline Glutathione oxidized $(\mu \mathrm{mol} / \mathrm{l})$ & $2.879 \pm 0.32$ & $2.146 \pm 0.56$ & $1.747 \pm 0.26$ \\
\hline Superoxide dismutase (conv. units) & $1.736 \pm 0.37$ & $1.323 \pm 0.29$ & $1.087 \pm 0.34$ \\
\hline
\end{tabular}




\section{Discussion}

The level of diene conjugates in the blood of newborn calves with easy labor severity in comparison with moderate labor severity was statistically significantly increased $(p<0.05)$, and 1.87 times with severe labor $(\mathrm{p}<0.01)$. The concentration of intermediate products of ketodienes and conjugated trienes in the blood of newborn calves with mild labor severity was statistically significantly increased by 1.75 times compared with moderate labor severity and 3.54 times with severe labor $(\mathrm{p}<0.01)$.

Therefore, the content of manol dialdigide in newborn calves after pathological childbirth is $1.125 \pm 0.34 \mu \mathrm{mol} / 1$, with an average severity of childbirth, it increases by 1.11 times, and in comparison with severe births by 1.35 times $(\mathrm{p}<0.05)$.

Therefore, as a result of our research, we obtained materials about the predominant formation of primary and intermediate products of free radical lipid oxidation - ketodienes, diene conjugates, and conjugated trienes in newborn calves after the Difficult Labor Syndrome. In newborn calves after the Difficult Labor Syndrome, the activity of oxidized glutathione $(2.879 \pm 0.32 \mu \mathrm{mol} / \mathrm{l})$ and superoxide dismutase $(1.736 \pm 0.37$ conv. units $)$ was lower than in the comparison group (average labor severity $-2.146 \pm 0.56 \mu \mathrm{mol} / \mathrm{l}$; and $1.323 \pm 0.29$ conv. units; severe labor - $1.747 \pm 0.26 \mu \mathrm{mol} / 1$ and $1.087 \pm 0.34$ conv. units, respectively), which indicates a decrease.

\section{Conclusion}

Difficult Labor Syndrome is recorded in $37.9 \%$ of newborn calves. Newborn calves assessed on the Apgar scale of 2 points, are assigned to the cluster class born after easy labor, 1 point - after moderate labor and 0 points for difficult labor. The characteristic features of newborn calves after light birth are the manifestation of statistical functions and free movement. In newborn calves born with moderate and severe labor severity, weakly expressed motor-food reflexes are manifested. Visible mucous membranes are pale in color. Breathing is slow and shallow. Heart sounds are weak, the pulse is arrhythmic, slowed down with a decrease in the pulse wave. Decrease in glucose concentration, increase in total bilirubin level by 1.9 times with moderate severity of labor and 2.5 times with severe course of labor. An excess of creatinine contributes to the liborilization of the function of eosinophils, as a result, a symptom develops due to sensitization of the body.

The studies carried out indicate that the concentration of double bonds in the blood of newborn calves after the Difficult Labor Syndrome is marked by an increase of $20.46 \%$ with an average severity of labor and $34.13 \%$ with a severe course of labor when compared with a mild severity of labor. The level of diene conjugates in the blood of newborn calves with mild labor severity in comparison with moderate labor severity was statistically significantly increased $(p<0.05$ ), and 1.87 times with severe labor $(p<0.01)$. The concentration of intermediate products of ketodienes and conjugated trienes in the blood of newborn calves with mild labor severity was statistically significantly increased by 1.75 times compared with moderate labor severity and 3.54 times with severe labor ( $p$ $<0.01)$.

Therefore, the content of manol dialdigide in newborn calves after pathological childbirth is $1.125 \pm 0.34 \mu \mathrm{mol} / 1$, with an average severity of childbirth, it increases by 1.11 times, and in comparison with severe births by 1.35 times $(\mathrm{p}<0.05)$.

As a result of our study, we obtained materials on the predominant formation of primary and intermediate products of free radical oxidation of lipids - ketodienes, diene conjugates, 
and conjugated trienes in newborn calves after the Difficult Labor Syndrome. In newborn calves after the Difficult Labor Syndrome, the activity of oxidized glutathione $(2.879 \pm 0.32 \mu \mathrm{mol} / \mathrm{l})$ and superoxide dismutase $(1.736 \pm 0.37$ conv. units $)$ was lower than in the comparison group (average labor severity - $2.146 \pm 0.56 \mu \mathrm{mol} / 1$; and $1.323 \pm 0.29 \mathrm{conv}$. units; severe labor $-1.747 \pm 0.26 \mu \mathrm{mol} / 1$ and $1.087 \pm 0.34$ conv. units, respectively), which indicates a decrease in the activity of antioxidant protection. The generalization of the data obtained indicates that the indicators of the LPO-AOP system have a high diagnostic information value.

So, with a decrease in superoxide dismutase less than 1.55 conv. units it is possible to reveal a violation of the functional state in $82.0 \%$ of newborn calves, and only in $25.0 \%$ of newborns this indicator will be uninformative for predicting their functional state. Reduced glutathione is among the considered indicators of the least sensitivity (26.0\%) and specificity (43.0 \%) in newborn calves after the Difficult Labor Syndrome. As follows from the presented data, the metabolic parameters that are traditionally used in the diagnostic algorithm of the functional state of newborn calves in some cases are less sensitive and specific than the indicators of the LPO-AOP system.

\section{References}

1. С. О. Лощинин, В. Н. Чучин, В. С. Авдеенко, Д. В. Кривенко, Вестник Саратовского Госагроуниверситета им. Н.И. Вавилова, 7 (2014)

2. С. О. Лощинин, В.Н. Чучин, В. С. Авдеенко, Д. В Кривенко, Известия Горского государственного аграрного университета, 51, 3 (2014)

3. Ю. Н. Алехин (Воронеж, автореф. дисс. док. вет. наук, 2013)

4. А. А. Катаранов (Саратов, автореф. дис. канд. вет. наук, 2005)

5. A. C. B. Berge, T. E. Besser, D. A. Moore, W. M. Sischo, J. Dairy Sci., 92, 1 (2009)

6. M. Epiney, F. Boehlen, M. Boulvain, J. Thromb. Haemost, 3, 2 (2005)

7. M. R. Syme, J. W. Paxton, J. A. Keelan, Clin. Pharmacokinet, 43, 8 (2004)

8. R. D. Caffarena, M. L. Casaux, C. O. Schild, M. Fraga, M. Castells, R. Colina, F. Giannitti, Brazilian Journal of Microbiology, 52, 2 (2021)

9. J. H. C. Costa, M. C. Cantor, H. W. Neave, Journal of Dairy Science, 104, 1 (2021)

10. S. Gupta, S. Abhishek, Shrivastava, R. J. Singh, P. Gogoi, B. Kumar, International Journal of Peptide Research and Therapeutics, 27, 2 (2021)

11. B. P. T. Hang, E. Wredle, J. Dicksved, Tropical Animal Health and Production, 53, 1 (2021)

12. C. Heinemann, C. D. Leubner, J. J. Hayer, J. Steinhoff-Wagner, Journal of Animal Science, 99, 1 (2021)

13. H. Kim, C. Oh, J. An, S. Baek, S. Bock, J. Kim, Nanomaterials, 11, 3 (2021)

14. M. G. Lopes, A. S. Alharthi, V. Lopreiato, E. Abdel-Hamied, Y. Liang, D. N. Coleman, J. J. Loor, Journal of Dairy Science, 104, 2 (2021)

15. A. Orihuela, L. I. Pérez-Torres, R. Ungerfeld,Tropical Animal Health and Production, 53, $1(2021)$

16. W. C. Van Voorhis, M. A. Hulverson, R. Choi,, W. Huang, S. L. M. Arnold, D. A. Schaefer, K. K. Ojo, Veterinary Parasitology, 289 (2021)

17. V. Weixler, R. Lapusca, G. Grangl, A. Guariento, M. Y. Saeed, D. B. Cowan, I. Friehs, Journal of Thoracic and Cardiovascular Surgery, 162, 1 (2021) 